\title{
Selenium hyperaccumulation offers protection from cell disruptor herbivores
}

\author{
Colin F Quinn ${ }^{1 \dagger}$, John L Freeman ${ }^{1,2,4 \dagger}$, Ray JB Reynolds', Jennifer J Cappa ${ }^{1}$, Sirine C Fakra ${ }^{3}$, Matthew A Marcus ${ }^{3}$, \\ Stormy D Lindblom', Erin K Quinn', Lindsay E Bennett ${ }^{1}$, Elizabeth AH Pilon-Smits ${ }^{1 *}$
}

\begin{abstract}
Background: Hyperaccumulation, the rare capacity of certain plant species to accumulate toxic trace elements to levels several orders of magnitude higher than other species growing on the same site, is thought to be an elemental defense mechanism against herbivores and pathogens. Previous research has shown that selenium (Se) hyperaccumulation protects plants from a variety of herbivores and pathogens. Selenium hyperaccumulating plants sequester Se in discrete locations in the leaf periphery, making them potentially more susceptible to some herbivore feeding modes than others. In this study we investigate the protective function of Se in the Se hyperaccumulators Stanleya pinnata and Astragalus bisulcatus against two cell disrupting herbivores, the western flower thrips (Frankliniella occidentalis) and the two-spotted spider mite (Tetranychus urticae).

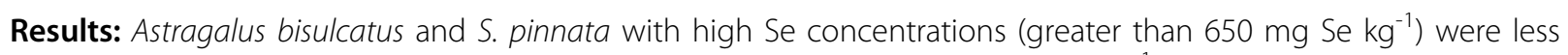
subject to thrips herbivory than plants with low Se levels (less than $150 \mathrm{mg} \mathrm{Se} \mathrm{kg}^{-1}$ ). Furthermore, in plants containing elevated Se levels, leaves with higher concentrations of Se suffered less herbivory than leaves with less Se. Spider mites also preferred to feed on low-Se A. bisulcatus and S. pinnata plants rather than high-Se plants. Spider mite populations on A. bisulcatus decreased after plants were given a higher concentration of Se. Interestingly, spider mites could colonize A. bisulcatus plants containing up to $200 \mathrm{mg} \mathrm{Se} \mathrm{kg}^{-1}$ dry weight, concentrations which are toxic to many other herbivores. Selenium distribution and speciation studies using microfocused X-ray fluorescence ( $\mu$ XRF) mapping and Se K-edge X-ray absorption spectroscopy revealed that the spider mites accumulated primarily methylselenocysteine, the relatively non-toxic form of Se that is also the predominant form of Se in hyperaccumulators.

Conclusions: This is the first reported study investigating the protective effect of hyperaccumulated Se against cell-disrupting herbivores. The finding that Se protected the two hyperaccumulator species from both cell disruptors lends further support to the elemental defense hypothesis and increases the number of herbivores and feeding modes against which Se has shown a protective effect. Because western flower thrips and two-spotted spider mites are widespread and economically important herbivores, the results from this study also have potential applications in agriculture or horticulture, and implications for the management of Se-rich crops.
\end{abstract}

\section{Background}

For many organisms, including mammals and many species of bacteria and algae, selenium (Se) is an essential trace element [1]. These organisms contain selenoproteins, some of which destroy free radicals that damage DNA [2]. In humans, Se supplementation has been

\footnotetext{
* Correspondence: epsmits@lamar.colostate.edu

+ Contributed equally

'Department of Biology, Colorado State University, Fort Collins, CO 80532 , USA

Full list of author information is available at the end of the article
}

shown to reduce the chance of getting cancer, including the devastating widespread lung and prostate cancers $[3,4]$. In addition, Se plays an essential role in thyroid function [5]. While Se is essential for many organisms, there is a narrow margin between deficiency and toxicity levels. Selenium toxicity can be both acute and chronic. Acute Se toxicity leads to "blind staggers" in livestock; the symptoms include staggered walking, impaired vision, paralysis and sometimes death. Chronic Se poisoning leads to hair and nail loss, fatigue, nausea and eventually death [6].
Ciomed Central

C 2010 Quinn et al; licensee BioMed Central Ltd. This is an Open Access article distributed under the terms of the Creative Commons Attribution License (http://creativecommons.org/licenses/by/2.0), which permits unrestricted use, distribution, and reproduction in any medium, provided the original work is properly cited. 
Selenium has no known essential function for higher plants, and elevated levels of Se are toxic to most plants [7]. This toxicity is due to the chemical similarity of Se and sulfur (S). Most plants inadvertently assimilate Se into proteins, leading to toxicity [1]. A few plant species have evolved to accumulate unusually large amounts of Se, as much as $1 \%$, or $10,000 \mathrm{mg} \mathrm{Se} \mathrm{kg}^{-1}$ dry weight (DW) $[8,9]$. These unique plants are called Se hyperaccumulators and they avoid Se poisoning by methylating SeCys to form methylselenocysteine (MeSeCys), which is relatively non-toxic because it does not get incorporated into proteins [10].

Hyperaccumulation is a phenomenon where plants accumulate particular elements to levels several orders of magnitude higher than other plant species growing on the same substrate [11]. Some other elements besides Se that can be hyperaccumulated by plants include aluminum (Al), arsenic (As), cadmium (Cd), manganese $(\mathrm{Mn})$, nickel $(\mathrm{Ni})$ and zinc $(\mathrm{Zn})$ [12]. Feist and Parker [13] defined Se hyperaccumulation as plants that con-

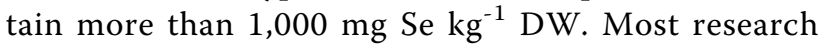
investigating the functional significance of hyperaccumulation has focused on and lent support to the elemental defense hypothesis, which states that plants have evolved to hyperaccumulate these various toxic elements as protection against herbivore and pathogen attacks [14]. Hyperaccumulated As, Cd, Ni, Zn and Se all have been shown to protect plants from herbivores and/or pathogens [15-19].

To date, Se hyperaccumulation has been shown to protect plants from a mammalian herbivore, the blacktailed prairie dog (Cynomys ludovicianus), as well as from several arthropod herbivores and two fungal pathogens [20-23]. Additionally, Se hyperaccumulating plants harbored fewer arthropods and arthropod species than comparable non Se hyperaccumulators growing in the same, seleniferous habitat [24]. Moreover, Se hyperaccumulating plants sequester Se in organs and tissues that are most susceptible to herbivore attack. For example, the Se in hyperaccumulator Astragalus bisulcatus (two-grooved milk vetch) is predominantly present in the leaf hairs, and Stanleya pinnata (Prince's plume), another Se hyperaccumulator, sequesters Se in epidermal cells in the leaf margins [9]. This uneven distribution of Se, which leaves some areas of the plant with lower concentrations of Se than others, may allow some herbivores, depending on their feeding mode, to avoid this elemental defense. Indeed, some herbivore species were found living on Se hyperaccumulating plants in the field and apparently were feeding on the Se-rich plant material, in view of the fact that they contained higher Se concentrations than individuals collected from nonhyperaccumulators [24]. Thus, it is important to investigate the effect of feeding mode on the herbivores' ability to feed on Se hyperaccumulating plants. The effect of feeding mode on herbivore susceptibility to hyperaccumulated elements is illustrated by the study by Jhee et al. [25] who found that the Ni hyperaccumulator Streptanthus polygaloides was protected from folivore herbivores but not vascular feeding herbivores. In addition, the Zn hyperaccumulator Thlaspi caerulescens was not protected from snail herbivory [26]

This study investigates the protective effect of Se hyperaccumulation against cell disruptor herbivore species, specifically the two-spotted spider mite (Tetranychus urticae) and western flower thrips (Frankliniella occidentalis). Both herbivores have been observed feeding on $A$. bisulcatus and S. pinnata in the greenhouse and both feed by piercing the cell surface with their mouthparts and sucking out the cell contents [27]. This study, the first to examine cell disruptor herbivores' sensitivity to Se hyperaccumulation, is ecologically relevant because both of these herbivores share habitats with Se hyperaccumulating plants $[13,28]$. Interestingly, western flower thrips and many Se hyperaccumulating plant species are native to the western United States and protection against thrips herbivory may have contributed to the evolution of Se hyperaccumulation. Both herbivores are also ecologically important pests. Two-spotted spider mites can have devastating effects on crop yields worldwide [29]. Outbreaks often occur after pesticide application inadvertently kills their predators [30]. Western flower thrips are native to the Western United States, but have been reported on all continents except Asia and Antarctica [31]. Through a combination of their herbivory and their notorious ability to transfer disease and develop pesticide resistance, western flower thrips can significantly reduce crop yields [32,33]. In this study we report a significant effect of plant Se accumulation on the response of two Se hyperaccumulators (A. bisulcatus and $S$. pinnata) to both cell disruptors, the western flower thrips and the two-spotted spider mite.

\section{Methods}

Plant material

Seeds of $A$. bisulcatus were obtained from plants growing at Pine Ridge Natural Area in Fort Collins, CO, USA $\left(40^{\circ} 32.70 \mathrm{~N}, 105^{\circ} 07.87 \mathrm{~W}\right)$. Pine Ridge Natural Area is a seleniferous habitat; the population of $A$. bisulcatus from which seeds were collected accumulates up to $10,000 \mathrm{mg} \mathrm{Se} \mathrm{kg}{ }^{-1}$ [34]. Seed germination and growth followed an arid western plant growth protocol previously used for Se hyperaccumulating plants and described by Sors et al. [35]. Plants were grown on prewashed Turface MVP (Profile Products LLC, Buffalo Grove, IL) in $25 \mathrm{~cm}$ diameter pots in greenhouse conditions $\left(24 / 20^{\circ} \mathrm{C}\right.$ day/night, $16-\mathrm{h}$ photoperiod, $300 \mu \mathrm{mol}$ $\mathrm{m}^{-2} \mathrm{sec}^{-1}$ photosynthetic photon flux). Three weeks after 
germination half of the plants received high-Se fertilizer treatments, $1 \mathrm{~g}$ of fertilizer (Miracle-Gro Excel, 15:5:15 Cal-Mag, The Scotts Co., Marysville, $\mathrm{OH}$ ) per liter of water combined with $20 \mu \mathrm{M} \mathrm{Na} \mathrm{SeO}_{4}$, while the other half received low-Se fertilizer treatments, $1 \mathrm{~g}$ of fertilizer per liter of water with $2 \mu \mathrm{M} \mathrm{Na} \mathrm{SeO}_{4}$, three times a week. After 20 weeks of growth plants were used for thrips and spider mite experiments as described below.

Stanleya pinnata seeds were obtained from Western Native Seed (Coaldale, CO, USA) and plants were grown from seed in pre-washed Turface MVP. Thirty-six plants were grown in a growth room $\left(24^{\circ} \mathrm{C} / 20^{\circ} \mathrm{C}, 12 \mathrm{~h} / 12 \mathrm{~h}\right.$ light/dark, $120 \mu \mathrm{mol} \mathrm{m}{ }^{-2} \mathrm{~s}^{-1}$ photosynthetic photon flux): 10 weeks after germination half of the plants were watered twice a week for 50 weeks with $1 \mathrm{~g}$ of fertilizer (Miracle-Gro Excel, 15:5:15 Cal-Mag, The Scotts Co., Marysville, $\mathrm{OH}$ ) per liter of water and $20 \mu \mathrm{M} \mathrm{Na}_{2} \mathrm{SeO}_{4}$, the other half were watered with $1 \mathrm{~g}$ of fertilizer per liter of water as a control. Plants were used for thrips and spider mite experiments as described below.

\section{Effects of Se on herbivory of $A$. bisulcatus by thrips}

To investigate thrips toxicity to Se and their preference to feed on high- or low-Se plants, both non-choice and choice experiments were conducted. For non-choice experiments high- and low-Se A. bisulcatus were infected with western flower thrips by placing three excised $A$. bisulcatus leaves previously harboring large populations of thrips on each plant. Thrips were initially acquired from $A$. bisulcatus plants growing in a greenhouse and suffering thrips infestation. Two high and low-Se plants were then placed in separate 20 g glass tanks that were kept in $24 / 20^{\circ} \mathrm{C}$ day/night, 16 -h photoperiod, $300 \mu \mathrm{mol} \mathrm{m}{ }^{-2} \mathrm{sec}^{-1}$ photosynthetic photon flux and watered 3 times a week either with $20 \mu \mathrm{M} \mathrm{Na}_{2} \mathrm{SeO}_{4}$ or without Se. Tanks were covered with $0.2 \mathrm{~mm}^{2}$ nylon mesh tops to prevent thrips transfer while still allowing gas exchange. For choice experiments plants were infected with thrips as described above and a high- and a low-Se plant were placed in the same glass tank. After three weeks of herbivory the percentage of young (mature leaves from the top five nodes), medium (leaves from middle nodes) and old (leaves from the bottom 3 nodes) leaves and the percentage of leaflets per leaf with visual signs of thrips herbivory were calculated on each plant. Non-choice experiments were repeated 6 times and choice experiments were repeated 4 times for highSe and 4 times for low-Se treatments. Selenium concentrations for young, medium and old leaves were measured as described below.

Effects of Se on herbivory of $A$. bisulcatus by spider mites Spider mite non-choice and choice experiments were also conducted using $A$. bisulcatus. For non-choice experiments 10 high- or low-Se plants grown as described above were placed in $20 \mathrm{~L}$ glass tanks that were placed in $24 / 20^{\circ} \mathrm{C}$ day/night, 16 -h photoperiod and $300 \mu \mathrm{mol} \mathrm{m} \mathrm{sec}^{-1}$ photosynthetic photon flux and covered with $0.2 \mathrm{~mm}^{2}$ mesh. Plants were watered either with $20 \mu \mathrm{M} \mathrm{Na} \mathrm{SeO}_{4}$ or without Se 3 times weekly. Each plant was inoculated with 100 spider mites that were collected from $A$. bisulcatus plants with high spider mite populations. The number of spider mites on each plant was counted after 7, 14 and 21 days and the percent of the population change was calculated for each plant. For choice experiments spider mites were given a choice to feed on high- or low-Se plants. One high- and one low-Se A. bisulcatus plant grown as described above was placed in a tank and 100 spider mites were placed on each plant. The number of spider mites on each plant was counted after 7, 14 and 21 days and percent population change was calculated. This experiment was repeated 7 times. Leaf Se concentrations of youngest mature leaves were compared between highand low-Se plants as described below.

In addition to choice and non-choice experiments, low-Se $A$. bisulcatus pre-infected with spider mites were provided with Se to determine if adding Se reduces established populations of spider mites. At the onset of the experiment low-Se $A$. bisulcatus plants that were being treated with $2 \mu \mathrm{m}$ Se were infected with large spider mite populations. For three weeks eight of the plants were provided with $40 \mu \mathrm{m}$ Se three times a week while eight others were provided with water as a control. The percent population change in spider mite population was recorded after 7, 14 and 21 days. Leaf Se concentration of the youngest mature leaves were measured before and after the experiment.

Spider mites from high-Se $A$. bisulcatus plants used in non-choice experiments were collected and analyzed for Se speciation. Samples were washed and flash-frozen using liquid nitrogen. Samples were kept frozen at $-80^{\circ} \mathrm{C}$ to prevent Se metabolism, and Se speciation was determined using XANES as described by Marcus et al. [36], using known selenocompounds as standards.

\section{Se speciation, X-ray microprobe measurements}

Spider mites from high-Se A. bisulcatus plants used in non-choice experiments were collected and analyzed for Se speciation. Samples were washed and flash-frozen using liquid nitrogen. Samples were kept frozen to prevent Se metabolism, and Se speciation was determined using XANES as described earlier [21,36], using well characterized selenocompounds as standards.

\section{Effects of Se on herbivory of S. pinnata by thrips}

Stanleya pinnata, another Se hyperaccumulating species, was also used to determine if Se protects against cell 
disrupting herbivores. Thrips were given a choice to feed on either high- or low-Se S. pinnata. Eighteen high-Se and 18 low-Se plants grown as described above were intermixed and placed in a growing room $(12 \mathrm{~h} / 12$ $\mathrm{h}$ light/dark, $120 \mu \mathrm{mol} \mathrm{m}{ }^{-2} \mathrm{~s}^{-1}$ photosynthetic photon flux) heavily infested with thrips. Plants were watered either with $20 \mu \mathrm{M} \mathrm{Na} \mathrm{SeO}_{4}$ or without Se 3 times weekly. After 4 weeks of being exposed to thrips herbivory the percentage of leaves with visual signs of thrips herbivory was compared between plants with and without Se. In addition, since within one $S$. pinnata plant Se is unevenly distributed we determined Se concentration of leaves with thrips herbivory and leaves without thrips herbivory from the same high-Se plant. For six of the $S$. pinnata plants treated with Se two similar-aged leaves per plant, one with herbivory and one without herbivory, were collected and analyzed for elemental concentrations using ICP-AES, as described below. To determine the variation in Se concentration of leaf age in plants not suffering herbivory, three leaves from consecutive nodes on the same high-Se $S$. pinnata plants were tested for Se concentration. This was repeated for 6 plants.

\section{Effects of Se on herbivory of S. pinnata by spider mites}

Ten high-Se and nine low-Se S. pinnata grown as described above were interspersed in a $50 \mathrm{~cm} \times 50 \mathrm{~cm}$ area on a greenhouse bench. Each plant was watered 3 times weekly either with $20 \mu \mathrm{M} \mathrm{Na} \mathrm{SeO}_{4}$ or without Se and was infected with spider mites by placing three leaves from other plants that harbored high concentrations of spider mites on the center of each plant. Spider mites were allowed to forage for two weeks, and herbivory was then scored by counting the number of leaves on each plant with and without visual signs of spider mite herbivory. The youngest mature leaves were collected from each plant and analyzed for Se concentration.

\section{Elemental analysis}

Elemental concentrations in leaves were determined by digesting approximately $100 \mathrm{mg}$ DW of leaf material in $1 \mathrm{ml}$ of nitric acid as described by Zarcinas et al. [37]. Using distilled water the samples were diluted to $10 \mathrm{ml}$ and elemental concentrations were determined using Inductively Coupled Plasma Atomic Emission Spectrometry (ICP-AES) as described by Fassel [38].

\section{Data analysis}

The software package JMP-IN (3.2.6, SAS Institute, Cary, NC) was used for all data analysis. Student's t-test was used to compare differences in herbivory between high-Se and low-Se plants and to compare elemental concentrations of leaf samples.

\section{Results}

\section{Effects of Se on herbivory of $A$. bisulcatus by thrips}

To investigate if the Se hyperaccumulator $A$. bisulcatus was protected from western flower thrips, both choice and non-choice studies were conducted with plants containing high and low concentrations of Se (the thrips are displayed in Figure 1A, B; high- and low-Se leaflets exposed to thrips herbivory are shown in Figure 1C, D). The non-choice experiments revealed that the fraction of leaves with herbivory was significantly less for high-Se plants than low-Se plants $(\mathrm{p}=0.018, \mathrm{t}=-2.832, \mathrm{n}=6$ for both high- and low-Se experiments), and that younger leaves suffered less herbivory than older leaves from both high- and low-Se plants (Figure 2A). In addition, fewer leaflets per leaf suffered thrips herbivory on high-Se than

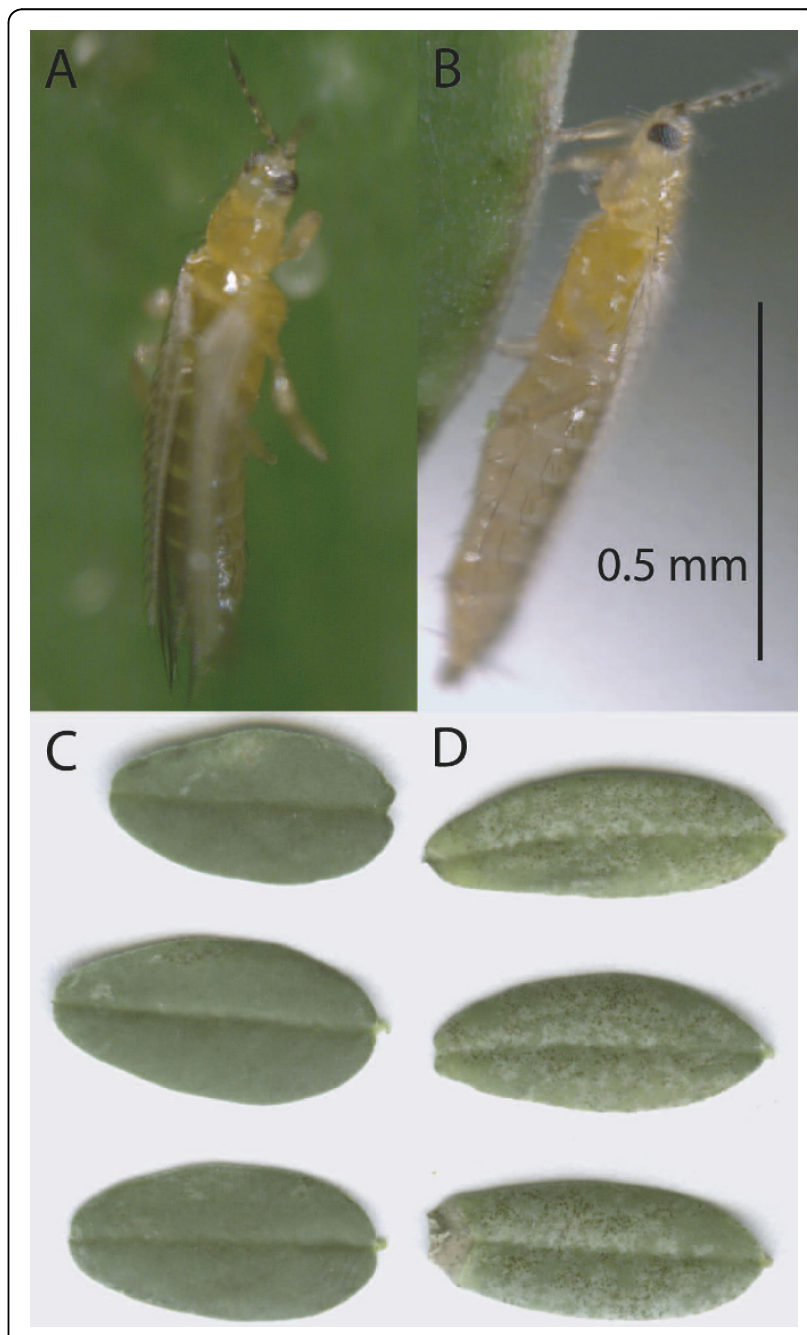

Figure 1 Western flower thrips feeding on A. bisulcatus. A, B: Thrips piercing A. bisulcatus leaflets, as viewed from the top (A) and side (B). C, D: Representative leaflets from high-Se (C) and low-Se (D) A. bisulcatus plants after exposure to thrips herbivory. Herbivory damage is apparent as white patches with black spots. 


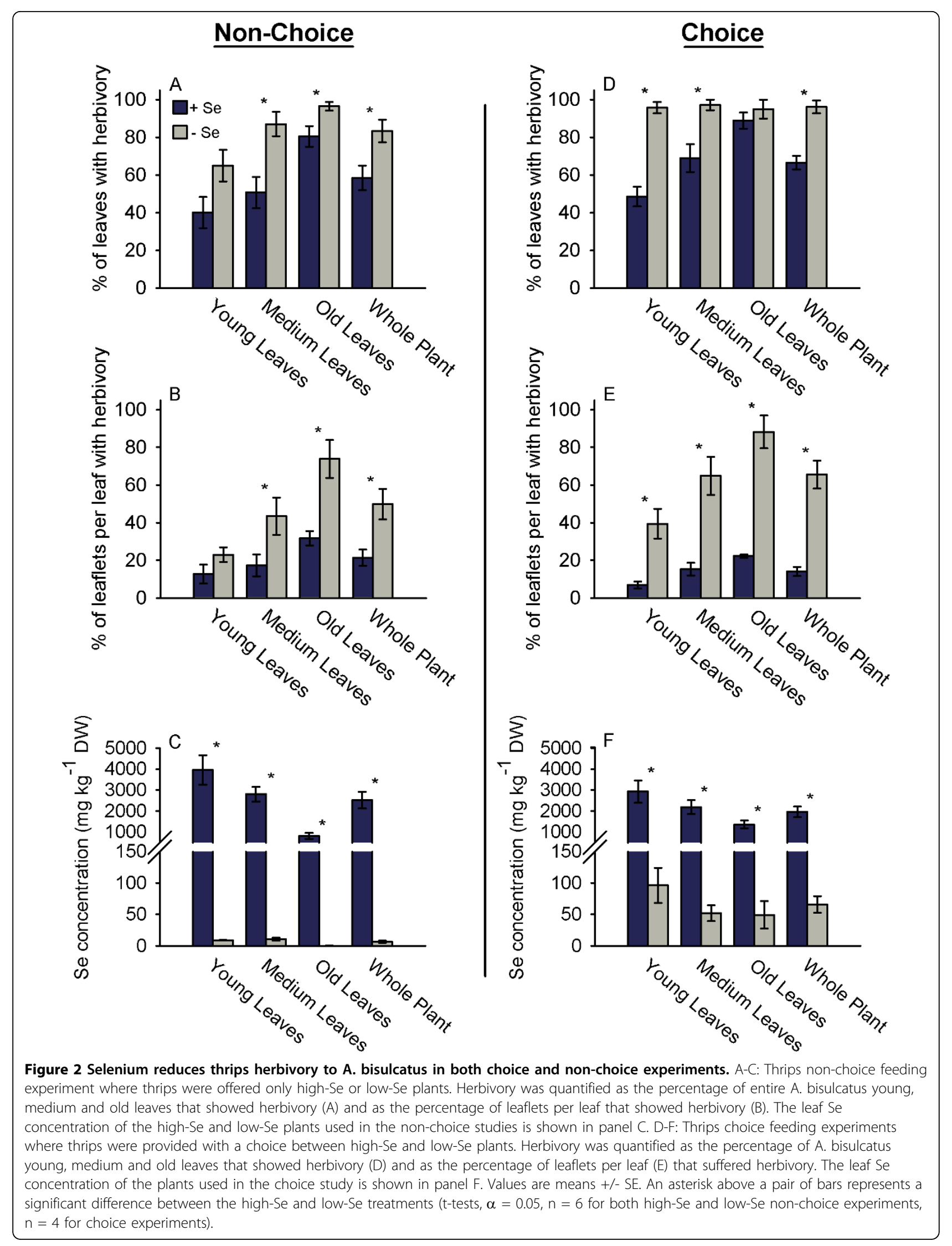


low-Se plants (Figure 2B; $\mathrm{p}=0.011, \mathrm{t}=-3.095, \mathrm{n}=6$ for both high- and low-Se experiments). Young leaves from high-Se plants contained roughly 1.5 -fold and 5 -fold higher Se concentrations than medium-aged and old leaves (respectively) of the same plants, ranging from $3,945 \mathrm{mg} \mathrm{Se} \mathrm{kg}^{-1}$ for young leaves and $812 \mathrm{mg} \mathrm{Se} \mathrm{kg}^{-1}$ for old leaves, while leaves from low-Se plants did not reach above $11 \mathrm{mg} \mathrm{Se} \mathrm{kg}^{-1}$ (Figure 2C).

When thrips were given a choice to feed on high- or low-Se plants they showed a significant preference to colonize low-Se plants. In these choice experiments lowSe leaves and leaflets suffered more herbivory than highSe leaves and leaflets (Figure 2D p $=0.001, t=-5.926$; Figure 2E, $\mathrm{p}<0.001, \mathrm{t}=-6.443 \mathrm{n}=4$ pairs of high- and low-Se plants). On high-Se plants young leaves suffered less herbivory than old leaves (Figure 2D, $\mathrm{p}=0.001, \mathrm{t}=$ $5.913, \mathrm{n}=4$ pairs of high- and low-Se plants). Similar to what was found for plants used in the non-choice thrips experiments, young leaves of the high-Se plants contained more Se than old leaves, 3,000 mg Se kg-1 compared to $1,350 \mathrm{mg} \mathrm{Se} \mathrm{kg}^{-1}$, respectively (Figure $2 \mathrm{~F}$ ). While in the choice study high-Se plants had many fold higher Se concentrations than low-Se plants, leaves from low-Se plants also contained around $100 \mathrm{mg} \mathrm{Se} \mathrm{kg}^{-1}$ DW in young leaves and approximately $50 \mathrm{mg} \mathrm{Se} \mathrm{kg}^{-1}$ DW in medium-aged and old leaves (Figure 2F).

Effects of Se on herbivory of $A$. bisulcatus by spider mites Non-choice and choice experiments were conducted to determine if Se effectively protected $A$. bisulcatus from another cell disruptor herbivore, the two-spotted spider mite. During the non-choice study spider mite populations only gradually increased in size on high-Se plants, whereas plants pre-treated with a low Se concentration showed an $800 \%$ spider mite population growth rate over three weeks (Figure 3A; $\mathrm{p}<0.001, \mathrm{t}=5.306, \mathrm{n}=$ 10 high- and 10 low-Se plants). When spider mites were given a choice to feed on high- or low-Se plants they preferred low-Se plants. The protective effect of Se was already detectable after one week, as populations of spider mites on high-Se plants decreased in size over time while populations on low-Se plants increased by over $200 \%$ after three weeks (Figure 3B; $\mathrm{p}<0.001, \mathrm{t}=6.004$, $\mathrm{n}=7$ high- and 7 low-Se plants). High-Se plants contained over 2,200 $\mathrm{mg} \mathrm{Se} \mathrm{kg}^{-1} \mathrm{DW}$ and low-Se plants contained $110 \mathrm{mg} \mathrm{Se} \mathrm{kg}^{-1} \mathrm{DW}(\mathrm{p}=0.009, \mathrm{t}=-4.792, \mathrm{n}$ $=3$ high- and 3 low-Se plants).

Another experiment was conducted to investigate the effect of adding Se to A. bisulcatus pre-infested with spider mites. Half of the plants infested with spider mites was treated with Se and the other half was given water as a control. After seven days the Se treatment had resulted in a $50 \%$ reduction in the population of spider mites; in contrast, the population of spider mites on plants not treated with Se increased by $50 \%$ during the same time period (Figure 4A, $\mathrm{p}=0.004, \mathrm{t}=3.416, \mathrm{n}=8$ high- and 8 low-Se plants). Three weeks after the start of the Se treatment the spider mite populations on the high-Se plants had decreased by almost $80 \%$ while the populations of spider mites on low-Se plants still showed an increase of $50 \%$ (Figure $4 \mathrm{~A}, \mathrm{p}<0.001$, $\mathrm{t}=$ $12.807, \mathrm{n}=8$ high- and 8 low-Se plants). Prior to conducting the experiment, all $A$. bisulcatus plants contained between $100-200 \mathrm{mg} \mathrm{Se} \mathrm{kg}{ }^{-1}$ DW. After the three-week experiment the high-Se plants contained

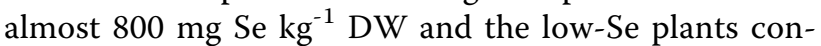
tained $100 \mathrm{mg} \mathrm{Se} \mathrm{kg}{ }^{-1}$ (Figure 4B, $\mathrm{p}=0.010, \mathrm{t}=2.870$, $\mathrm{n}=8$ high- and 8 low-Se plants).

Since the spider mites appeared to tolerate plant Se concentrations up to $150 \mathrm{mg} \mathrm{Se} \mathrm{kg}{ }^{-1}$ we collected spider mites off Se-treated plants to investigate the mechanism of their relatively high Se tolerance at the biochemical level. Selenium speciation studies using Se K-edge (Xray absorption near-edge structure (XANES)) spectroscopy and least square linear combination fitting (LCF) of the XANES spectra using standard compounds revealed that spider mites store Se primarily as an organic $\mathrm{C}-\mathrm{Se}-\mathrm{C}$ form similar to methylselenocysteine (MeSeCys) (Figure 5A-C).

\section{Effects of Se on herbivory of S. pinnata by thrips}

To further investigate if Se hyperaccumulators are protected from cell disrupting herbivores we used another Se hyperaccumulating plants species, S. pinnata, and again used thrips in a choice herbivory experiment. The thrips preferred to feed on S. pinnata plants without Se when given a choice between high- and low-Se plants (Figure 6A, $\mathrm{p}<0.001, \mathrm{t}=-10.333, \mathrm{n}=18$ high- and 18 low-Se plants). Within the Se-treated plants, leaves with elevated Se suffered less herbivory than similar-aged leaves on the same plants with lower Se levels (Figure $6 \mathrm{~B}, \mathrm{p}=0.012, \mathrm{t}=-3.056, \mathrm{n}=6 \mathrm{high}-$ and 6 low-Se plants). The leaves that were compared had similar concentrations of other elements beside Se (Figure 6C). To determine if the difference in Se concentration found in each pair of leaves was a response to herbivory or rather a leaf age-related difference in Se concentration to which the herbivore responded, Se concentration as a function of leaf age was investigated in more detail in plants without herbivory. Three leaves from consecutive nodes on each of six high-Se plants were analyzed for Se. The youngest of the three leaves contained a higher Se concentration than the oldest-aged leaf (Figure 7).

\section{Effects of Se on herbivory of S. pinnata by spider mites}

Spider mites were given a choice to feed on either highSe or low-Se S. pinnata to determine if elevated Se concentrations protected $S$. pinnata from spider mite 


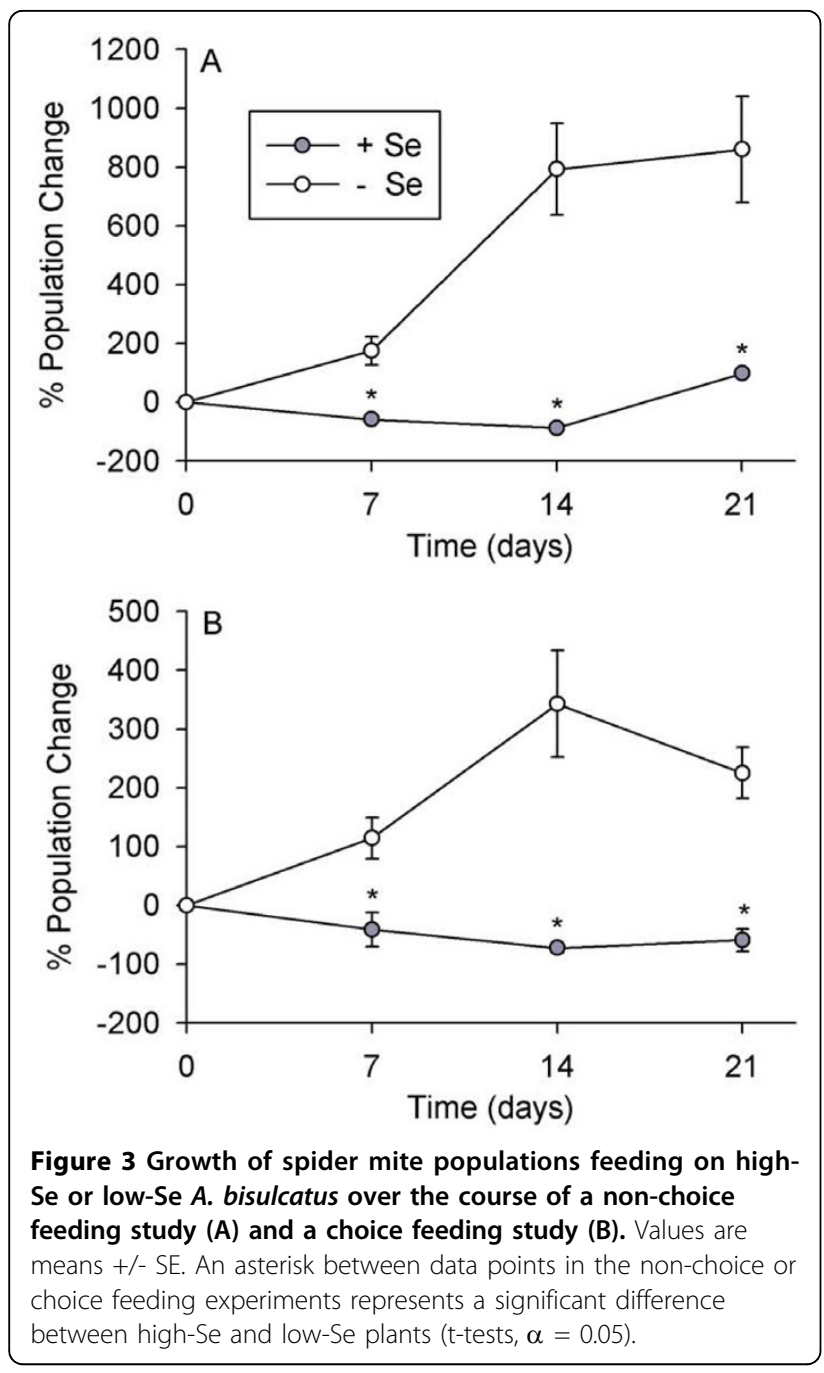

herbivory. On plants with elevated Se only $35 \%$ of leaves suffered spider mite herbivory while over $75 \%$ of leaves from low-Se plants suffered spider mite herbivory $(\mathrm{p}=$ $0.002, \mathrm{t}=3.617, \mathrm{n}=10$ high and 9 low-Se plants).

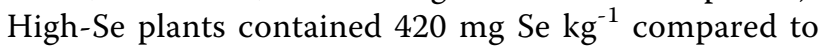
low Se plants, which only had $50 \mathrm{mg} \mathrm{Se} \mathrm{kg}{ }^{-1}$ ( $\mathrm{p}=0.007$, $\mathrm{t}=-3.078, \mathrm{n}=10$ high and 9 low-Se plants).

\section{Discussion}

These results expand on previous studies investigating the functional significance of Se hyperaccumulation. The earlier studies have shown that elevated Se can protect plants from arthropod folivore herbivores (grasshoppers, caterpillars), grazing mammalian herbivores (prairie dogs), phloem-feeding arthropods (aphids) and leaf and stem/root fungal pathogens $[18,20,21,23]$. This is the first study to show that Se protects hyperaccumulating plants from cell disrupting herbivores. This study provides evidence that two Se hyperaccumulating

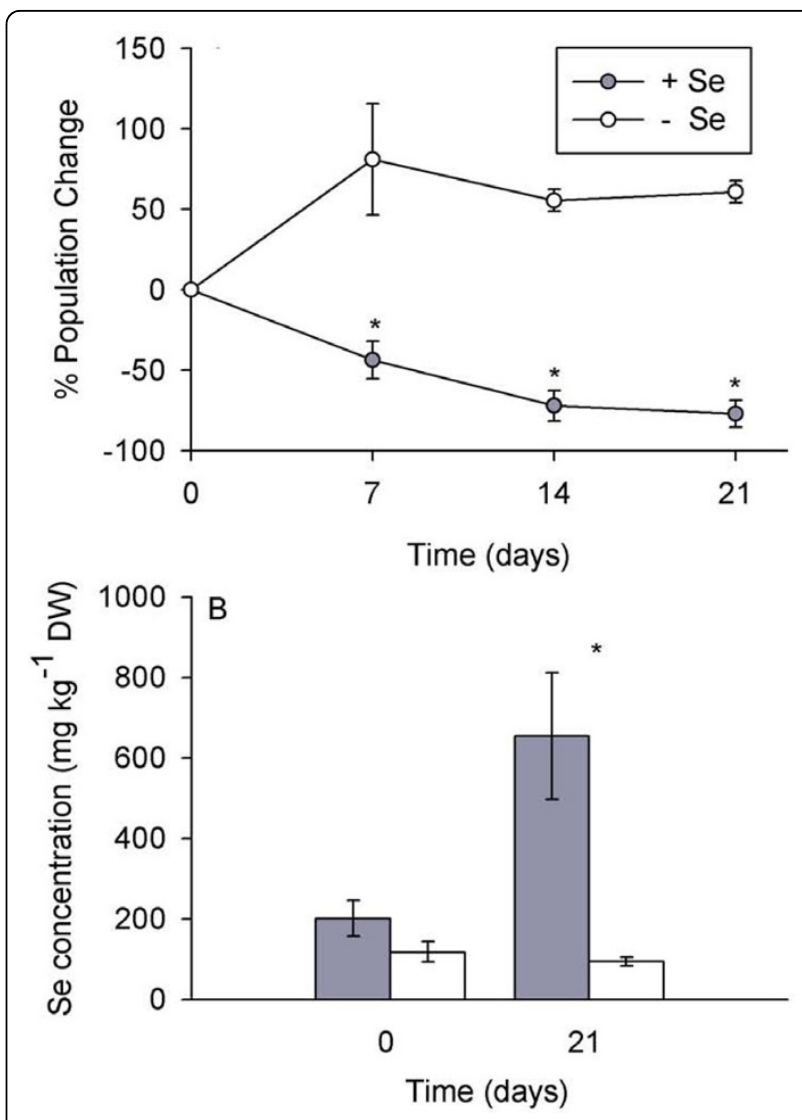

Figure 4 Selenium added to spider mite-populated $A$. bisulcatus plants reduced spider mite population growth. $A$ : Percent population change of established spider mite populations on A. bisulcatus over the course of a 3-week high-Se or low-Se treatment. B: Selenium concentration of plants at the beginning and end of the experiment. Values show means +/- SE. An asterisk between data points (A) or bars (B) represents a significant difference between the high- and low-Se treatments (t-test, $\alpha=$ $0.05, n=10$ for non-choice experiments, $n=7$ for choice experiments).

species, S. pinnata and $A$. bisulcatus, are protected against two ecologically relevant and economically important cell disruptor herbivores, the two-spotted spider mite and the western flower thrips, only when containing elevated Se concentrations. The non-choice studies showed that high-Se plants suffered less spider mite and thrips herbivory. The choice studies demonstrated that spider mites and thrips preferred low-Se $A$. bisulcatus and S. pinnata plants over high-Se plants. Furthermore, within a single plant, low-Se leaves suffered more thrips herbivory than high-Se leaves. Studies using A. bisulcatus showed that thrips preferred to feed on older leaves, which contained less Se. Studies with $S$. pinnata showed that leaves with high concentrations of Se suffered less thrips and spider mite herbivory than low-Se leaves and that younger leaves, even when only 

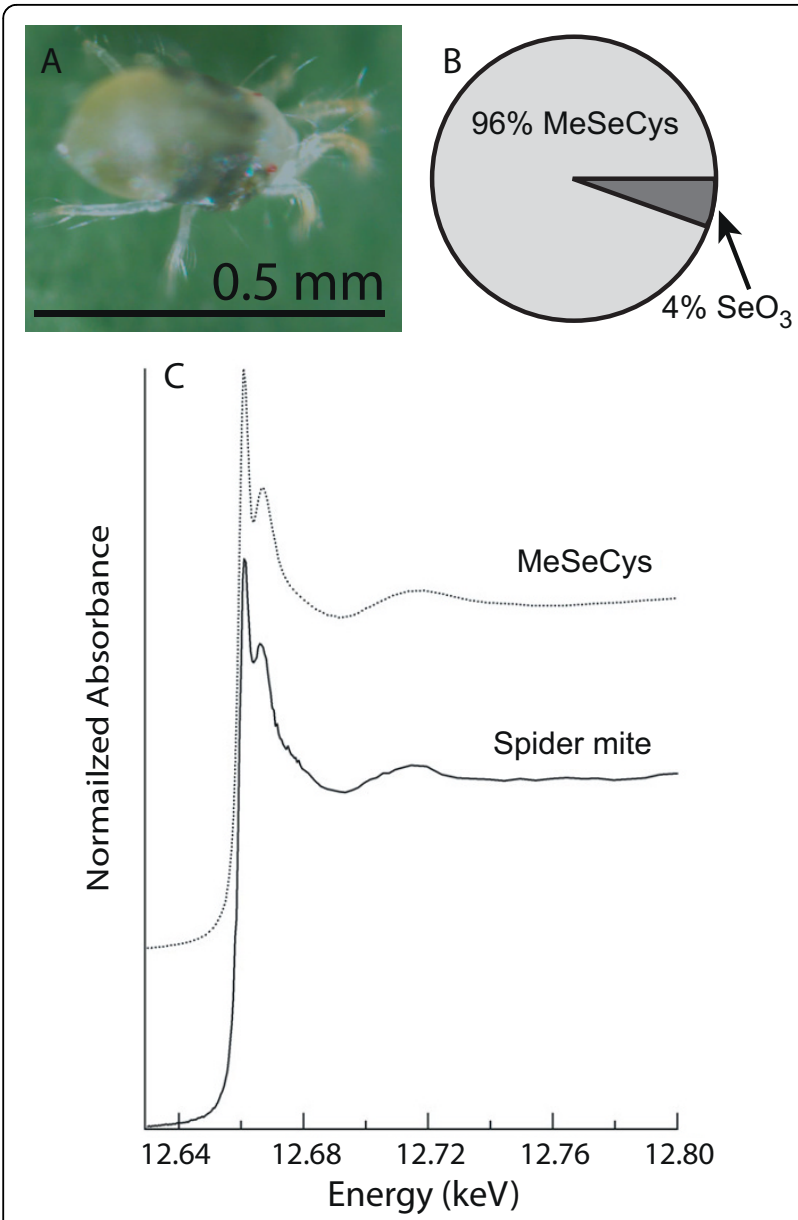

Figure 5 Selenium speciation in spider mites collected from Se-rich $\boldsymbol{A}$. bisulcatus plants. X-ray analysis of near-edge spectra (XANES) revealed that two-spotted spider mites collected from Serich $A$. bisulcatus plants (shown in panel $A$ ) contained primarily methylselenocysteine ( $B, C)$. The XANES Se spectra of the spider mites and of the methylselenocysteine standard compound are shown in panel $C$.

one node apart, had higher Se concentrations than older leaves. Those results suggest that these plants preferentially sequester Se in their younger leaves, which may be more valuable than older leaves because of higher photosynthesis rates [39], and in doing so are successful in protecting what may be considered their more valuable parts against these herbivores. Interestingly, in nonchoice studies we did not find significant differences in thrips herbivory damage on young leaves of high- and low-Se plants but did find more thrips herbivory on low-Se medium aged and old leaves compared to highSe medium aged and old leaves (Figure 2A,B). It is possibly that these young leaves contain more nutrients than older leaves, which is true in other plant species [40], and therefore are a more attractive food source for herbivores. The results of this study lend further
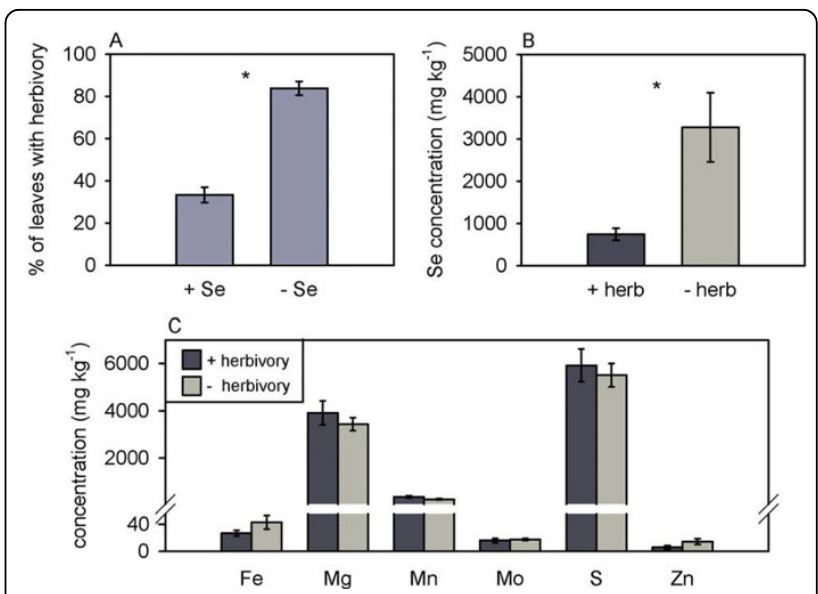

Figure 6 Selenium prevents thrips herbivory to S. pinnata in both choice and non-choice studies. A: Choice feeding experiment quantifying thrips herbivory of S. pinnata plants treated with or without $\mathrm{Se}$, quantified as percentage of leaves per plant showing herbivory. B: Selenium concentration in plants treated with $\mathrm{Se}$, comparing leaves that experienced thrips herbivory with leaves showing no herbivory. C: Elemental concentration of Fe, Mg, Mn, $\mathrm{Mo}, \mathrm{S}$ and $\mathrm{Zn}$ in plants treated with $\mathrm{Se}$, comparing leaves that experienced thrips herbivory with leaves showing no herbivory. Values are means +/- SE. An asterisk between a pair of bars represents a significant difference between the two treatments ( $t$ tests, $\alpha=0.05, \mathrm{n}=18$ ).

support to the hypothesis that Se hyperaccumulation serves as protection against herbivore attacks, and expands the list of herbivores against which Se is effective.

Herbivore feeding mode can be an important factor in plant-herbivore interactions. It is likely that some herbivores can circumvent plant defenses, including

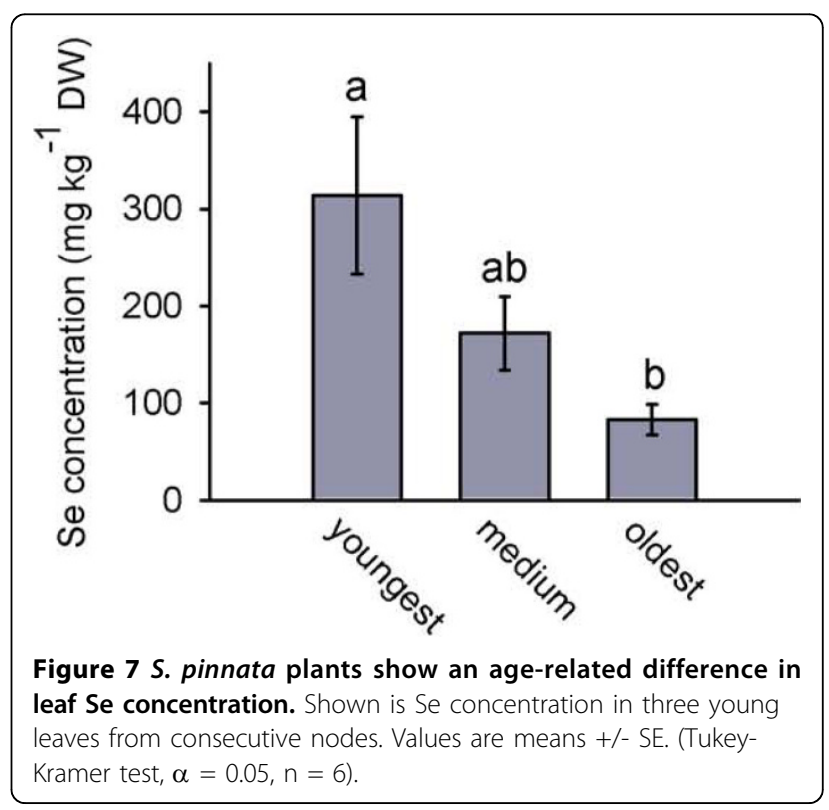


elemental defense, as a result of feeding modes [41,42] and that different hyperaccumulating plants are protected from different groups of herbivores. For example, $\mathrm{Ni}$ hyperaccumulation does not appear to protect plants from xylem and phloem feeding herbivores [25], while elevated Se, even at concentrations as low as $10 \mathrm{mg}$ Se $\mathrm{kg}^{-1} \mathrm{DW}$, can protect plants from the phloem-feeding green peach aphid [18]. Studies investigating Se distribution in Se hyperaccumulating plants suggests that they are better protected from some feeding modes than others. Leaves of S. pinnata sequester Se in the periphery of the leaves, in the epidermal cell layer, which is expected to be particularly effective against many folivores, like grasshoppers and caterpillars [9]. Astragalus bisulcatus leaves sequester Se in trichomes, which may act as an initial defense mechanism against a variety of feeding types [9].

Interestingly, it appears that spider mites can tolerate plant Se concentrations in hyperaccumulators up to $\sim 150 \mathrm{mg} \mathrm{Se} \mathrm{kg}^{-1} \mathrm{DW}$, concentrations that are toxic to many other herbivores (Figure 4A, B) [18,22]. Selenium speciation studies revealed that the spider mites accumulated an organic form of Se indistinguishable from MeSeCys (Figure 5B, C). This form of Se is less toxic than many other forms of Se because it is not incorporated into proteins [10]. The same form of Se was found in Se hyperaccumulator plants as well as in Se-tolerant herbivores found feeding on hyperaccumulators [21]. If the spider mites accumulate MeSeCys as well, this may contribute to their tolerance of relatively high concentrations of Se. It should be noted, however, that XANES does not effectively distinguish between various $\mathrm{C}-\mathrm{Se}-\mathrm{C}$ compounds, including MeSeCys, selenomethionine, and Se-cystathionine [9] and therefore it is possible that the mites accumulated a more toxic form of Se, or a mixture of these organic selenocompounds. This would explain why, at higher Se levels (around $420 \mathrm{mg} \mathrm{Se} \mathrm{kg}^{-1} \mathrm{DW}$ for

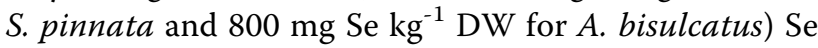
effectively protected the plants, even against spider mites.

These results have important implications for managing Se-rich agricultural or natural areas and Se phytoremediation or biofortification crops. Crops in seleniferous habitats and plants used for Se phytoremediation often do not accumulate more than $150 \mathrm{mg} \mathrm{Se}$ $\mathrm{kg}^{-1}$ [43]. While these plants may be protected by their low Se levels from folivore arthropods, they may still be susceptible to spider mite herbivory. On the other hand, Se hyperaccumulating plants, which typically contain more than 1,000 $\mathrm{mg} \mathrm{Se} \mathrm{kg}^{-1} \mathrm{DW}$ [24], likely are protected against both folivores and spider mites. This combined protective effect of Se accumulation against such a wide variety of herbivores may have been an important driving force for the evolution of Se hyperaccumulation.

\section{Conclusions}

Herbivores with different feeding modes may respond differently to hyperaccumulation in plants, as was suggested by Jhee et al. [25]. Because Se hyperaccumulating plants preferentially allocate Se to specific locations they may leave other locations vulnerable to herbivore attacks. This study shows that Se hyperaccumulating plants are protected from two economically important cell disrupting herbivores. The western flower thrips is considered a major pest because it is known to feed on plants in over 62 different families including many crop species [44], they effectively transfer viruses to crop species [45] and they rapidly develop pesticide resistance $[46,47]$. Two-spotted spider mites are also known to target many crops, such as fruit trees and vegetables, and can also develop resistance to pesticides [48]. The results of this study provide support for the elemental defense hypothesis and have implications for management of seleniferous habitats and Se phytoremediation. Selenium may act as a natural pesticide in Se-rich crops and plants used for Se phytoremediation in areas such as the western United States, where two-spotted spidermites, western flower thrips and Se hyperaccumulators all occur and where Se-rich agriculture is present. The observed avoidance of Se-rich plants by herbivores may also reduce the probability of Se movement and bioconcentration in the food chain. However, the ability of spi-

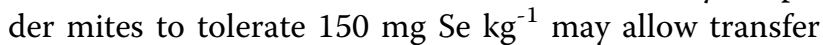
of Se into higher trophic levels, which is an area that needs to be further investigated.

\section{Acknowledgements}

This research was supported by grants \#IOB-0444471 and \#IOS-0817748 from the National Science Foundation to EAHPS. We thank David Steingraeber, Arathi Seshadri and Mark Paschke for helpful comments on the manuscript. We would also like to thank 2 anonymous reviewers for helpful comments that improved the manuscript. The Advanced Light Source is supported by the Office of Science, Basic Energy Sciences, Division of Materials Science of the U.S. Department of Energy (DE-AC02-05CH11231).

\section{Author details \\ 'Department of Biology, Colorado State University, Fort Collins, CO 80532, USA. ${ }^{2}$ Agricultural Research Service, U.S. Department of Agriculture, Parlier, CA 93648, USA. ${ }^{3}$ Advanced Light Source, Lawrence Berkeley National Laboratory, Berkeley, CA 94720, USA. ${ }^{4}$ California State University Fresno, Center for Irrigation Technology, Fresno CA 93740, USA.}

\section{Authors' contributions}

CFQ, JLF, RJBR and EAHPS conceived and coordinated the experiments in this study. SCF performed $\mu$ XRF and $\mu$ XAS data analyses. All authors assisted with the experiments. CFQ, JLF and EAHPS drafted the manuscript. All authors read and approved the final manuscript. 
Received: 28 May 2010 Accepted: 27 August 2010

Published: 27 August 2010

\section{References}

1. Stadtman TC: Selenium biochemistry. Annu Rev Biochem 1990, 59:111-127.

2. Steinbrenner $\mathrm{H}$, Sies $\mathrm{H}$ : Protection against reactive oxygen species by selenoproteins. Biochimica et Biophysica Acta - General Subjects 2009, 1790:1478-1485.

3. Clark LC, Combs GF Jr, Turnbull BW, Slate EH, Chalker DK, Chow J, Davis LS, Glover RA, Graham GF, Gross EG, et al: Effects of selenium supplementation for cancer prevention in patients with carcinoma of the skin: a randomized controlled trial. J Amer Med Assoc 1996, 276:1957-1963.

4. Shin SH, Yoon MJ, Kim M, Kim Jl, Lee SJ, Lee YS, Bae S: Enhanced lung cancer cell killing by the combination of selenium and ionizing radiation. Oncol Rep 2007, 17:209-216.

5. Kato MA, Finley DJ, Lubitz CC, Zhu BX, Moo TA, Loeven MR, Ricci JA, Zarnegar R, Katdare M, Fahey TJ: Selenium decreases thyroid cancer cell growth by increasing expression of GADD153 and GADD34. Nutr cancer 2010, 62:66-73.

6. Oliveira KD, Franca TN, Nogueira VA, Peixoto PV: Diseases associated with selenium poisoning in animals. Pesquisa Vet Brasil 2007, 27:125-136.

7. Anderson JW: Selenium interactions in sulfur metabolism. In Sulfur nutrition and assimilation in higher plants - regulatory, agricultural and environmental aspects. Edited by: De Kok LJ. The Hague, Netherlands: SPB Academic; 1993:49-60.

8. Beath OA, Gilbert CS, Eppson HF: The use of indicator plants in locating seleniferous areas in Western United States. I. General. Amer J Bot 1939, 26:257-269.

9. Freeman JL, Zhang LH, Marcus MA, Fakra S, Pilon-Smits EAH: Spatial imaging, speciation and quantification of selenium in the hyperaccumulator plants Astragalus bisulcatus and Stanleya pinnata. Plant Physiol 2006, 142:124-134

10. Brown TA, Shrift A: Exclusion of selenium from proteins in seleniumtolerant Astragalus species. Plant Physiol 1981, 67:1951-1953.

11. Baker AJM, Brooks RR: Terrestrial higher plants which accumulate metallic elements - a review of their distribution, ecology and phytochemistry. Biorecovery 1989, 1:81-126.

12. Reeves RD, Baker AJM: Metal accumulation in plants. In Phytoremediation of toxic metals: using plants to clean up the environment. Edited by: Raskin I, Ensley BD. New York: Wiley; 2000:193-229.

13. Feist LJ, Parker DR: Ecotypic variation in selenium accumulation among populations of Stanleya pinnata. New Phytol 2001, 149:61-69.

14. Boyd RS, Martens SN: The raison d'être for metal for metal hyperaccumulation by plants. In The vegetation of ultramafic (serpentine) soils. Edited by: Baker AJM, Proctor J, Reeves RD. Andover, UK: Intercept; 1992:279-289

15. Pollard AJ, Baker AJM: Deterrence of herbivory by zinc hyperaccumulation in Thaspi caerulescens (Brassicaceae). New Phytol 1997, 135:655-658.

16. Jhee EM, Dandridge KL, Christy AM Jr, Pollard AJ: Selective herbivory on low-zinc phenotypes of the hyperaccumulator Thlaspi caerulescens (Brassicaceae). Chemoecology 1999, 9:93-95.

17. Boyd RS, Davis MA, Wall MA, Balkwill K: Nickel defends the South African hyperaccumulator Senecio coronatus (Asteraceae) against Helix aspersa (Mollusca: Pulmonidae). Chemoecology 2002, 12:91-97.

18. Hanson B, Lindblom SD, Loeffler ML, Pilon-Smits EAH: Selenium protects plants from phloem feeding aphids due to both deterrence and toxicity. New Phytol 2004, 162:655-662.

19. Rathinasabapathi B, Rangasamy M, Froeba J, Cherry RH, McAuslane HJ, Capinera JL, Srivastava M, Ma LQ: Arsenic hyperaccumulation in the Chinese brake fern (Pteris vittata) deters grasshopper (Schistocerca americana) herbivory. New Phytol 2007, 175:263-369.

20. Hanson B, Garifullina GF, Lindbloom SD, Wangeline A, Ackley A, Kramer K Norton AP, Lawrence CB, Pilon Smits EAH: Selenium accumulation protects Brassica juncea from invertebrate herbivory and fungal infection. New Phytol 2003, 159:461-469.

21. Freeman JL, Quinn CF, Marcus MA, Fakra S, Pilon-Smits EAH: Seleniumtolerant diamondback moth disarms hyperaccumulator plant defense. Curr Biol 2006, 16:2181-2192.
22. Quinn CF, Freeman JL, Galeas ML, Klamper EM, Pilon-Smits EAH: The role of selenium in protecting plants against prairie dog herbivory: implications for the evolution of selenium hyperaccumulation. Oecologia 2008, 155:267-275.

23. Freeman $J \mathrm{~L}$, Quinn CF, Lindblom SD, Klamper EM, Pilon-Smits EAH: Selenium protects the hyperaccumulator Stanleya pinnata against blacktailed prairie dog herbivory in native seleniferous habitats. Amer J Bot 2009, 96:1075-1085.

24. Galeas ML, Klamper EM, Bennett LE, Freeman JL, Kondratieff BC, Quinn CF, Pilon-Smits EAH: Selenium hyperaccumulation reduces plant arthropod loads in the field. New Phytol 2008, 177:715-724.

25. Jhee EM, Boyd RS, Eubanks MD: Nickel hyperaccumulation as an elemental defense of Streptanthus polygaloides (Brassicaceae): influence of herbivore feeding mode. New Phytol 2005, 168:331-343.

26. Noret N, Meerts P, Tolrà R, Poschenrieder C, Barceló J, Escarré J: Palatability of Thlaspi caerulescens for snails: influence of $\mathrm{Zn}$ and glucosinolates. New Phytol 2005, 165(3):763-771.

27. Tomczyk A, Kropczynska D: Effects on the host plant. In Spider mites: their biology, natural enemies and control. Edited by: Helle W, Sabelis MW. Amsterdam: Elsevier; 1985:317-327.

28. Strand LL: Integrated Pest Management for Potatoes in the Western United States California: University of California Agriculture and Natural Resources, 2 2006.

29. Berlinger MJ: Pests. In The tomato crop: a scientific basis for improvement. Edited by: Atherton JG, Rudich J. New York: Chapman and Hall; 1986:391-441.

30. Hardman JM, Franklin JL, Jensen KIN, Moreau DL: Effects of pesticides on mite predators (Acari: Phytoseiidae) and colonization of apple trees by Tetranychus urticae. Phytoparasitica 2006, 34:449-462.

31. Brunner PC, Frey JE: Habitat-specific population structure in native western flower thrips Frankliniella occidentalis (Insecta, Thysanoptera). $J$ Evol Biol 2010, 23:797-804.

32. Immaraju JA, Paine TD, Bethke JA, Robb KL, Newman JP: Western flower thrips (Thysanoptera: Thripidae) resistance to insecticides in coastal California greenhouses. J Econ Entomol 1992, 85:9-14.

33. Williams MR: Cotton Insect Losses. Procedings of Beltwide Cotton Production: 3-6 January 2006; Memphis, TN Conference by the National Cotton Council of America, Memphis, TN 2006, 1151-1204.

34. Galeas ML, Zhang LH, Freeman JL, Wegner M, Pilon-Smits EAH: Seasonal fluctuations of selenium and sulfur accumulation in selenium hyperaccumulators and related non-accumulators. New Phytol 2007, 173:517-525.

35. Sors TG, Ellis DR, Na GN, Lahner B, Lee S, Leustek T, Pickering IJ, Salt DE: Analysis of sulfur and selenium assimilation in Astragalus plants with varying capacities to accumulate selenium. Plant J 2005, 42:785-797.

36. Marcus MA, MacDowell AA, Celestre R, Manceau A, Miller T: Beamline 10.3.2 at ALS: A hard X-ray microprobe for environmental and materials sciences. J Synchrotron Radiation 2004, 11:239-247.

37. Zarcinas B, Cartwright AB, Spouncer LR: Nitric acid digestion and multielement analysis of plant material by inductively coupled plasmaspectrometry. Commun Soil Sci Plan 1987, 18:131-146.

38. Fassel VA: Quantitative elemental analyses by plasma emission spectroscopy. Science 1978, 202:183-191.

39. Kitajima K, Mulkey SS, Samaniego M, Wright SJ: Decline of photosynthetic capacity with leaf age and position in two tropical pioneer species. Am Journal of Bot 2002, 89:1925-1932.

40. Aerts R: Nutrient resorption from senescing leaves of perennials: are there general patterns? J Ecol 1996, 84:597-608.

41. Gatehouse JA: Plant resistance towards insect herbivores: a dynamic interaction. New Phytol 2002, 156:145-169.

42. Karban R, Agrawal AA: Herbivore offense. Annu Rev Ecol Syst 2002, 33:641-664.

43. Stapleton JJ, Bañuelos GS: Biomass crops can be used for biological disinfestation and remediation of soils and water. Calif Agr 2009, 63:41-46.

44. Tommasini MG, Maini S: Frankliniella occidentalis and other thrips harmful to vegetable and ornamental crops in Europe. In Biological Control of Thrips Pests. Edited by: Loomans AJM, van Lenteren JC, Tommasini MG, Maini S, Riudavets J. Wageningen, The Netherlands: Wageningen Agricultural University Papers; 1995:1-42. 
45. Cho JJ, Mau RFL, German TL, Hartmann RW, Yudin LS, Gonsalves D, Provvidenti R: A multidisciplinary approach to management of tomato spotted wilt virus in Hawaii. Plant Dis 1989, 73:375-383.

46. Herron $\mathrm{G}$, James $\mathrm{T}$ : Monitoring insecticide resistance in Australian Frankliniella occidentalis Pergande (Thysanoptera: Thripidae) detects fipronil and spinosad resistance. Aust J Entomol 2005, 44:299-303.

47. Herron GA, James TM: Insecticide resistance in Australian populations of western flower thrips, Frankliniella occidentalis Pergande (Thysanoptera: Thripidae). Gen Appl Entomol 2007, 36:1-5.

48. Flexner $\mathrm{JL}$, Westigard PH, Croft BA: Field reversion of organotin resistance in the two-spotted spider mite (Acari, Tetranychidae) following relaxation of selection pressure. J Econ Entomol 1988, 81:1516-1520.

doi:10.1186/1472-6785-10-19

Cite this article as: Quinn et al:: Selenium hyperaccumulation offers protection from cell disruptor herbivores. BMC Ecology 2010 10:19.

\section{Submit your next manuscript to BioMed Central} and take full advantage of:

- Convenient online submission

- Thorough peer review

- No space constraints or color figure charges

- Immediate publication on acceptance

- Inclusion in PubMed, CAS, Scopus and Google Scholar

- Research which is freely available for redistribution

Submit your manuscript at www.biomedcentral.com/submit 